\section{Access to generic antiretrovirals: inequality, intellectual property law, and international trade agreements}

\author{
Acceso a antirretrovirales genéricos: desigualdad, \\ derecho de propiedad intelectual y acuerdos \\ comerciales internacionales
}

I Department of Social
Medicine, Harvard Medical
School, Boston, U.S.A.
2 Department of Medicine,
Brigham and Women's
Hospital, Boston, U.S.A.
Correspondence
A. Castro
Program in Infectious
Disease and Social
Change, Department of
Social Medicine,
Harvard Medical School.
641 Huntington Avenue,
Boston, MA 02115, U.S.A.
arachu_castro@hms.harvard.edu

\section{Abstract}

The governments of numerous low- and middleincome countries are currently instituting rules that strengthen changes in domestic intellectual property legislation, often made to conform to the mandates of "free" trade agreements signed with the United States. These measures frequently include intellectual property provisions that extend beyond the patent law standards agreed upon in recent World Trade Organization negotiations, which promised to balance the exigencies of public health and patent holders. In this paper, we analyze the concern that this augmentation of patent law standards will curtail access to essential medicines, particularly as they relate to the AIDS pandemic. We critically examine the potential threats posed by trade agreements vis-à-vis efforts to provide universal access to antiretroviral medications and contend that the conditioning of economic development upon the strengthening of intellectual property law demands careful attention when public health is at stake. Finally, we examine advocacy successes in challenging patent law and conclude that greater advocacy and policy strategies are needed to ensure the protection of global health in trade negotiations.

Acquired Immunodeficiency Syndrome; Antiretroviral Agents; Drug Industry; Generic Drugs
Arachu Castro 1

Michael Westerhaus 2

\section{Introduction}

International trade law and its impact on access to medications for the treatment of HIV have generated passionate debate in recent years 1 . Multinational pharmaceutical companies, World Trade Organization (WTO) members, United States and European Union trade representatives, and health care activists have clashed over the issue of antiretroviral (ARV) provision to people living with AIDS in developing countries. The debate centers on the value and role of patents obtained for pharmaceutical products, drug-manufacturing techniques, and forms of drug delivery. Recently, these arguments have intensified amidst an increased U.S. pursuit of "free" trade agreements - which include strong intellectual property provisions - with low - and middle-income countries throughout the world.

In this paper, we examine the key areas of concern regarding trade agreements and access to antiretroviral therapy (ART). In order to provide the necessary backdrop for engaging these concerns, we first present an overview of patent law history with particular salience for healthrelated issues and we link this history with the current context of global AIDS and access to ARVs. Next we map out the key claims and questions that compel current arguments on the role of patent law, followed by a critical examination of the concerns surrounding the impact of trade agreements on intellectual property law and 
their potential threat to global health. Finally, we conclude with a number of suggestions for advocacy and policy strategies that aim to ensure and promote access to ARVs.

\section{Patent law as it relates to public health}

International patent law dates back to 1883 when the Paris Convention established that a patent lasts for 20 years and must be filed in each country where protection is sought within the span of one year from the primary patent filing date 2. The precepts of the Paris Convention dictated patent law structure for decades, until the intensification of globalization in the mid$20^{\text {th }}$ century triggered a redoubling of efforts to regulate intellectual property. In 1967, the World Intellectual Property Organization (WIPO) was established to regulate the production, distribution, and use of knowledge; this organization continues to function today under the umbrella of the United Nations. In the late 20th century, in response to mounting pressure for global standardization of intellectual property law in order to parallel an expansion of international economic trade flows, countries participating in the Uruguay Round of trade negotiations developed the Trade-Related Aspects of Intellectual Property Rights (TRIPS) Agreement between 1986-1994. These negotiations also gave birth to the WTO, which came into existence on January 1st, 1995. Exactly a year later, WIPO and WTO entered into a cooperative agreement to share information and monitor the enforcement of TRIPS. Today the WTO has 149 member states, over two-thirds of which are low - and middle-income countries 3 .

The TRIPS agreement originally required the standardization of intellectual property law among all member states by 2005 3. In other words, all WTO member states were required to develop and apply patent law, including protection of pharmaceutical products. Essentially, the agreement prohibits the production, exportation, and importation of a generic drug for which a patent exists. The TRIPS agreement did provide for one exception to this prohibition by allowing for compulsory licensing - or the permission of a third party to make, use, or sell a patented invention without the patent owner's consent - under which generic versions of patented drugs could be produced. However, the TRIPS agreement failed to explicitly define the circumstances under which compulsory licenses could be used. Moreover, countries invoking the compulsory licensing provision in the TRIPS agreement were required to have in-country manufacturing capacities for pharmaceuticals. As most resource-poor countries lack the resources or infrastructure to produce medications, this stipulation meant that many countries, especially those most in need of ARVs, were not in a position to take advantage of the compulsory licensing provision unless allowed to parallel import - that is, import from a country that has purchased or produced medications within the legal boundaries of patent law and subsequently offers these medications for international resale.

In 2001, WTO delegates gathered in Doha, Qatar attempted to better define the boundaries of compulsory licensing by issuing a strong statement favoring its use in public health emergencies 4 . This statement, now referred to as the Doha Declaration, affirmed the priority of public health over patent status. Additionally, paragraph six of the Doha Declaration identified the need to resolve the conundrum for countries lacking domestic manufacturing capabilities yet desperately needing medications for epidemics such as AIDS. In what became known as the "paragraph 6 problem", WTO officials ordered the TRIPS council to develop a plan by the end of 2002 .

Reaching consensus on the "paragraph 6 problem", however, created great debate among TRIPS council members. The U.S. led an effort to restrict paragraph 6 of the Doha Declaration to certain diseases, namely, AIDS, malaria, tuberculosis, and other infectious diseases creating epidemics. Further, the U.S. worked to limit the number of countries that could benefit from the importation of generic medications ${ }^{5}$. On $\mathrm{Au}-$ gust 30,2003 , the TRIPS council finally issued a temporary decision stating that countries without manufacturing capacities - a definition that still remains unclear - could declare compulsory licenses and on that basis alone legally import generic medications. In December 2005, the TRIPS council agreed to make this decision permanent if two-thirds of WTO members ratified the amendment by December 1st 2007.

Lastly, delegates also agreed at Doha that the least developed countries (of 50 countries defined as such by the United Nations, 32 are WTO members) were not obliged to implement patent law for pharmaceuticals until January 1, 2016. The list of Least Developed Countries that areWTO members includes: Angola, Bangladesh, Benin, Burkina Faso, Burundi, Cambodia, Central African Republic, Chad, Democratic Republic of Congo, Djibouti, Gambia, Guinea, Guinea-Bissau, Haiti, Lesotho, Madagascar, Malawi, Maldives, Mali, Mauritania, Mozambique, Myanmar, Nepal, Niger, Rwanda, Senegal, Sierra Leone, Solomon Islands, Togo, Uganda, United Republic of Tanzania, and Zambia 3,6. Advocates for improving access to drugs in developing countries 
viewed the Doha Declaration with great optimism, although some have cautioned against its limitations and uncertainties 7 . Companies in places such as Brazil, India, Cuba, Thailand, Guatemala, and South Africa have worked under this framework to produce generic ARVs at a greatly reduced cost.

However, compulsory licenses, the primary mechanism offered for public health protection by the TRIPS agreement and the Doha Declaration, have been rarely utilized 8 . The exact procedures for issuing a compulsory license for ARV production remain unclear and largely untested. Significant international pressure also exists against declaring compulsory licenses, as seen when Brazil threatened to issue compulsory licenses for efavirenz, lopinavir/ritonavir, and tenofovir 9,10. For these reasons in part, only four countries - Malaysia (2004), Indonesia (2004), Zambia (2004), and Mozambique (2004) - have thus far issued compulsory licenses for ARV production 11 .

As reflected in this circuitous history of efforts to bridge patent law and public health concerns, intellectual property obstacles - in addition to hurdles involving public health financing, medical and public health infrastructure, and drug quality - have encumbered efforts to scale-up global ARV distribution.

\section{Global AIDS and access to antiretrovirals}

Addressing the issue of ART distribution requires urgency. Currently, 39.4 million people in the world live with HIV. In 2005, 3.1 million people in the world died of AIDS. Of these, about 570,000 were children 12 . In South Africa, where 5,300,000 individuals are currently HIV-positive, it is estimated that the population in 2005 was 16 percent lower than it would have been in the absence of AIDS 13. The AIDS pandemic has created dire circumstances in many parts of the world, threatening economic stability, security, food production, and health and education infrastructure 14 .

These figures are especially disturbing when juxtaposed with the fact that medications exist that dramatically decrease HIV mortality and morbidity and that, when ARVs are made available, HIV treatment in resource-poor settings has been shown to be not only possible but extremely successful 15. Despite these facts, the international community, including governments, nongovernmental organizations, and pharmaceutical companies, are generally failing to provide ART to those who need it most, and as a result millions are dying prematurely of an otherwise treatable disease. WHO estimates that out of 6.5 million people who need ART worldwide, only 1.3 million (20 percent) currently receive the medications 16 . In Africa, the region most devastated by the pandemic, this percentage is 17 percent, up from 8 percent in 200417.

Between December 2003 and 2005, the World Health Organization (WHO) led an effort to rapidly scale-up HIV treatment throughout the world. This endeavor, known as the 3 by 5 Initiative, aimed to have three million people on ARV treatment by the end of 2005. During the initiative, the number of patients receiving ART in low- and middle-income countries increased from 400,000 to 1.3 million 16. Although short of the December 2005 goal - due partially to donor delay in making financial contributions - the initiative achieved significant progress in mobilizing the expansion of ARV treatment. Other reasons cited to explain the failure to reach the initiative's targets include poorly harmonized partnerships, constraints on the procurement and supply of drugs, diagnostics and other commodities, strained human resources capacity and other critical weaknesses in health systems, and difficulties in ensuring equitable access 18 . Unless these issues, some of which are directly affected by patent law, are rigorously addressed, further efforts to expand ARV treatment risk being empty promises.

Most types of antiretrovirals, of which 12 are included in the most recent WHO list of essential medicines 18 , are produced by generic manufacturers in India 19. Built on substantial economic and infrastructure capabilities for drug production, Indian generic companies such as Cipla and Ranbaxy have become the major suppliers of low-cost ART regimens throughout the developing world 20. Médecins Sans Frontières 21 estimates that 50 percent of the medications used for ART in low - and middle-income countries are produced in India. However, this supply of cheap generic medications may soon end following India's enforcement of TRIPS-compliant patent law since January 1st, 2005 as a consequence of stipulations laid out in the 1996 TRIPS agreement - changes that have caused great concern among those working to expand HIV treatment. Believing that strengthened patent law will increase opportunities for foreign investment in India, the Indian government passed amendments in March 2005 that strengthen intellectual property law and could hinder the future production of medications for health emergencies such as AIDS 22,23.

These developments have generated worldwide concern that access to affordable ART, especially for second - and third-line antiretrovi- 
rals, may be severely constrained under India's new patent law. In a December 17, 2004 letter to the Indian Minister of Health, Jim Y. Kim 24, then director of the Department of HIV/AIDS at the $\mathrm{WHO}$, cautioned India against implementing new patent law that hinders public health efforts both within and outside of India. Indian activists have declared that "the Government is adopting a simplistic, conformist approach of hurriedly 'aligning' our Patent Law to the coercive version of TRIPS" 25 and asserted that "the need of the hour is to follow a more creative and independent approach, while still remaining within the broad contours of TRIPS" 25. Many worry that patent law changes in India will abrogate the Indian supply of cheap, generic ART, thereby resulting in higher medication prices and the imposition of structural obstacles that may unnecessarily thwart efforts to deliver ART to the poor. This issue of access to medicines is at the heart of the current and historical controversy over the role of intellectual property law, and forces consideration of whether the right to intellectual property for life-saving medications should take precedence over the right to health.

\section{Patent law dispute amidst the AIDS pandemic}

As patent law has a direct impact on drug pricing and access to medicines, it is vital for healthcare professionals to understand the divergent positions of research-based pharmaceutical companies, the activist organizations who oppose them, and the arguments inflaming the dispute over patent law. First, dispute arises over the relationship between patent law, pharmaceutical company research expenditures, and the development of novel medications. Research-based pharmaceutical companies argue that patents are necessary to promote innovation and allow for the recovery of research and development expenditures. Current patent law, by providing a 20-year monopoly to patentees, prevents generic pharmaceutical companies from quickly replicating and producing newly discovered medications at minimal cost. Drug companies claim that earlier entry by generic companies onto the market would undercut the ability of the pharmaceutical business to offset resources risked in developing medications, which is why, they argue, that 20-year patents provide sustainability for the pharmaceutical business and ensure funding for continued research activities. Researchbased drug companies assert that, without patent protection, their ability to recover costs and their incentives to develop new drugs would be limited 26 .
Health activists and academics focused on addressing inequality in access to health care have challenged these arguments. They claim that, in the U.S., a large portion of drug research is conducted at universities or government centers and is publicly funded by the National Institutes of Health (NIH). Such was the case for d4T, an antiretroviral drug used to treat AIDS. Jerome Horowitz of the Michigan Cancer Foundation first synthesized d4T in 1966 along with ddC, two years after having synthesized AZT - all three of them with grants from the National Cancer Institute 27 . In 1988, NIH-funded researchers at Yale University discovered the capability of $\mathrm{d} 4 \mathrm{~T}$ to treat HIV disease 28 . Yale later licensed it to New Yorkbased Bristol-Myers Squibb (BMS), which started to market it in 1994 - boosting Yale's annual patent royalty income nearly tenfold ${ }^{29}$. In 1998 , BMS, along with other pharmaceutical companies, sued the South African government's Medicines Act to prevent, among other provisions, the compulsory licensing of patented drugs, which included d4T. In 2001, upon pressure from Yale students and activist groups, Yale University reached an agreement with BMS by which the company removed patent-related obstacles that were preventing access to $\mathrm{d} 4 \mathrm{~T}$ in South Africa 30 . In April 2001 - after pressure from many sectors around the world, including from within the U.S. and the European Union - the pharmaceutical companies dropped the case $?$.

Examples such as this one raise questions about pharmaceutical company claims that patent protection and high drug costs are always necessary to allow for the recouping of research expenditures. Additionally, recent reports suggest that marketing costs, such as commercial advertisements and gifts to medical doctors, are included by pharmaceutical companies in the research and development costs of drugs 31 . Others claim that only a small fraction of the financial benefits of selling drugs is reinvested in research and development 32 . Such information challenges the research expenditure claims made by pharmaceutical companies.

Activists also argue that there is little evidence that current intellectual property law creates incentives for the development of new drugs. An analysis of a small sample of pharmaceutical inventive activity before and after compulsory licensing showed no uniform decline in scientific innovation 33 , challenging the assumption that patent protection is necessary to foster the development of new drugs. Furthermore, current patent protections do not necessarily create financial incentives for the development of desperately needed drugs, such as a malaria vaccine, in poor countries: between 1975 and 1997, only 
13 out of 1,223 new drugs introduced globally were specifically targeted towards diseases disproportionately affecting poor countries 34 .

In support of the research-based pharmaceutical companies, some argue that patent laws have historically played very little role in inhibiting access to essential medicines in the developing world - instead asserting that poverty and poor health infrastructure are the primary obstacles to ARV distribution 35,36. Additionally, poor drug quality, inadequate public health infrastructure, understaffed clinics and hospitals, lack of political commitment, and underfinancing of HIV treatment programs are cited as major factors obstructing the provision of ART. While recognizing the ability of these factors to impede access to ARV and working for their elimination, health activists counter that patent law-because of its role in determining drug prices - also demands critical appraisal of its impact on access to medicines.

Health activists and academics argue that current patent protection, by eliminating competition, generally leads to higher prices 37,38 , which directly obstructs the promotion of global health equity. Due to the enormity of the AIDS pandemic, health activists and academics have recently focused on HIV treatment, charging that current intellectual property law and patent law impede the purchase of ARVs in resourcepoor settings and allow pharmaceutical companies to monopolize the markets of developing nations 7,39,40,41. As a result, the cost of ARVs far exceeds personal and national budgets, and the development of more affordable generic alternatives is proscribed. In their view, alternatives to current patent law and incentive mechanisms, such as regulatory flexibility 38,42 or "pull" programs to stimulate research for vaccine development 43 , are crucial to alleviate the suffering of people living with treatable diseases in poor countries.

Finally, health activists assert that the 20 -year conferred length of a patent monopoly was decided over a century ago, at a time when drug development, production, marketing, and distribution occurred at a different pace. Based on this observation, it could be argued that if the current length of monopolies were shortened, the resulting increased competition could contribute to lowering the cost of medications while creating incentives for innovation.

With the recent proliferation by the U.S. of trade agreements, which in part involve intellectual property law, the dispute has intensified. Pharmaceutical companies and governments such as the U.S., Japan, Switzerland, and the European Union insist that standardization of patent law, based on U.S. standards, must occur throughout the world in an age of global economic networks 44 . For the U.S., trade agreements provide an opportunity to assert and implement strict, uniform patent law in the world. Drug companies argue that such provisions will, in fact, increase technology transfer to developing nations and ensure future funding for research dedicated to tackling the world's greatest diseases. Health activists warn that intellectual property measures built into current trade agreements will compromise national healthcare in low - and middle-income countries by creating immense barriers to the procurement of affordable essential medicines 45 .

In Guatemala, for example, this issue did not go unnoticed. Vice-President Eduardo Stein 46 clearly stated in January 2006: "Multinational corporations have been pressing their case and they want extra protection for their patents. We already have legislation that adheres strictly to the World Trade Organization guidelines. They are trying to force us to change that legislation again when we already went through a heap of trouble during the negotiations to safeguard popular access to generic medications". He was not alone in voicing concerns about the impact of the Central American Free Trade Agreement (CAFTA) in access to medicines, joined by Guatemala. On July 29, 2005, a Guatemalan producer of generic medications (personal communication, 2005) had noted: "Yesterday CAFTA was approved, and now we will be pressed to go to further protection. This means that from now on, even if the products do not have a patent, they are provided with a period of protection of five years. (...) We are worried that a lot of Central American people who are not covered by social security are going to die from AIDS, they cannot buy the new medicines, and we are not going to be able to produce an affordable and good quality product till the protection is finished. Our Ministry of Health does not have effective programs to give medicines to these people, so the problem is really difficult. (...) I hope that this information will help you gain some conscience in the good Americans, because I'm afraid CAFTA is going to bring more poverty to our countries when we are going to be flooded with all your rice and corn that are produced with government aid. Here the poor farmers do not get a penny of aid from our government. These treaties can make some industries grow, but they can also starve half of the nation, and create a climate of violence that how are we going to control?".

These concerns are tightly linked with an emerging policy threat on access to essential medicines: U.S. strengthening of patent law through trade agreements. 


\section{United States trade policy and access to antiretrovirals}

In January 2003, President Bush announced his five-year plan that would allocate US $\$ 15$ billion to global programs aimed at HIV treatment and prevention 47 . Now referred to as the President's Emergency Plan for AIDS Relief (PEPFAR), this initiative endeavors, in 15 focus countries, to support treatment for 2 million people living with AIDS, to prevent 7 million new infections, and to support care for 10 million people infected and affected by HIV by 2008. After just eight months of operation, PEPFAR reported rapid progress in achieving its aims - by March 2005, 155,000 people were receiving ART, 1.2 million women and infants had benefited from mother-to-child prevention measures, and 1.7 million individuals infected and affected by HIV/AIDS were receiving supportive care under its auspices 48 .

However, recent U.S. trade policy threatens to undermine these advancements in improved access to ARVs. Agreements with countries in Asia and Latin America have conditioned "free" trade on the expansion of intellectual property rights for multinational pharmaceutical companies holding ARV patents, among other essential medicines. Specifically, these agreements extend patent rights beyond the 20 -year period, freeze generic manufacturing of ARVs in the country, protect the manufacturers' drug testing data for five years - known as data exclusivity - and limit options for compulsory licensing. Additional measures include a reduction in the number of inventions, such as "diagnostic, therapeutic, and surgical methods" that can be excluded from patent law, the allowance of known substances to be patented again for each new use, and provisions requiring national drug regulatory authorities to block registration of generic medications. Broadened intellectual property rights beyond those negotiated in the WTO TRIPS agreement are now referred to as “TRIPS-plus" measures 45.

"TRIPS-plus" measures are included in agreements recently signed and in others currently being negotiated. For example, in May 2004, the U.S. signed the CAFTA with Costa Rica, El Salvador, Guatemala, Honduras, and Nicaragua - and the Dominican Republic, which was added in August 2004. CAFTA requires both data exclusivity for five years [Article 15.10.1(a)] and patent extensions to offset delays in the granting of a patent (Article 15.9.6) 49. The U.S. and the Andean countries (Colombia, Ecuador, Peru, and potentially Bolivia) had discussed a similar agreement known as the U.S. - Andean Free Trade Agreement; however, the agreement fell apart over issues related to intellectual property law. In that agreement, among the provisions pushed by the U.S. that affected intellectual property law were strict limitations on compulsory licensing (Article 8.4), the elimination of Andean countries' rights to not grant patents on diagnostic, therapeutic, and surgical methods (Article 8.1 and 8.2), and the prohibition of parallel importation (Article 8.4) 50. Following the collapse of the regional FTA, the U.S. started to pursue bilateral FTAs with each Andean country. In December 2005, Peru broke with the caution exercised by the other Andean countries and signed an FTA with the U.S. that included strengthened patent law provisions, including 5-year data exclusivity and permitted expansion of patent length beyond 20 years 51,52. Colombia followed suit in February 2006 and signed an FTA with the U.S. 53. Additionally, the U.S. has signed similar trade agreements with Singapore, Chile, and Morocco, and is currently working on agreements with Panama and the Southern African Custom Union (Botswana, Lesotho, Namibia, South Africa, and Swaziland).

Concern exists among health activists, academics, developing country governments, and clinicians working in resource-poor settings that these agreements will greatly augment the power of research-based pharmaceutical companies in the markets of developing nations, thereby greatly compromising access to ARVs for the poor. The extension of patent law beyond the provisions delineated in the TRIPS agreement should warrant great unease. Trade agreements currently being negotiated may severely constrain generic production of drugs, when generics are the primary source of affordable medications in resource-poor settings. Thus, "TRIPS-plus” provisions continue a tradition of limited access to ART for the poor by instituting measures that condone high drug prices.

In addition to the uneasiness expressed by activists, clinicians, and researchers, similar concerns have been voiced from within the U.S. government. On September 30, 2004, 12 members of the U.S. House of Representatives submitted a letter to President Bush expressing opposition to the intellectual property rights provisions in CAFTA and the trade agreement negotiations with the Andean countries and Panama. Authors of the letter criticized the lack of specific language on the rights to compulsory licensing and parallel importation and the imposition of five-year blockades on drug testing data. They warned that these agreements could violate the TRIPS agreement and the Doha Declaration 54 . 


\section{Prioritizing health in patent law and trade agreements}

Since the inception of the TRIPS agreement in 1996, significant opposition to its intellectual property implications has arisen. At times, challenges to strengthened patent law have resulted in victories protecting the health of the poor. The Treatment Action Campaign, a South African advocacy group devoted to promoting access to ARVs, has succeeded in challenging multinational pharmaceutical control of ARV markets in South Africa 55. Brazil, a country that has provided comprehensive HIV care to all citizens in need since 1996, including highly active antiretroviral therapy $56,57,58$ received a direct challenge in 2001 from the U.S. after Brazil threatened to issue compulsory licenses for some ARVs. The U.S. filed a complaint in the WTO Dispute Settlement Body, charging that Article 68 in Brazilian intellectual property law - which permits compulsory licensing if the patent holder does not produce a product locally within three years of the granting of the patent - directly violates TRIPS. Brazil countered that Article 68, to the contrary, promoted the objective established in TRIPS of ensuring the protection of public health in pharmaceutical matters. Under enormous international pressure, the U.S. withdrew its WTO complaint against Brazil, marking a victory for health activists 7 . Since that time, by utilizing the threat of compulsory licensing, the Brazilian government has been able to negotiate enormous price reductions for ARVs from major pharmaceutical companies 59. These and other examples illustrate that the validity of strong patent law in the face of the AIDS pandemic can be undermined.

Additionally, challenges directed against the strengthening of intellectual property law have focused on trade agreements. In 1998, the issue of access to essential medicines with respect to intellectual property law as defined by TRIPS received great attention at the World Health Assembly. At that time a resolution was recommended by its executive committee for consideration by member states which stressed that public health must be a top priority in policies involving pharmaceuticals and health, including trade agreements. Due to fierce opposition by the U.S., the European Union, and the research-based pharmaceutical lobby, the resolution was tabled for further discussion 60. However, at the following World Health Assembly in 1999, a resolution was passed that urged all member states to "explore and review their options under international agreements, including trade agreements, to safeguard access to essential drugs" 61.
Further, the WHO "Revised Drug Strategy" 62 began incorporating a mandate to determine the impact of the TRIPS Agreement and other trade agreements on access to medications. While its initial involvement in intellectual property law was extremely controversial, WHO has now established itself as a respected authority on monitoring intellectual property law and access to medications, even serving as an ad hoc observer on the WTO TRIPS Council 7,62. Most recently, in the 2004 World Health Assembly, a resolution was passed which "urges member states, as a matter of priority, to encourage that bilateral trade agreements take into account the flexibilities contained in the WTO TRIPS Agreement and recognized by the Doha Ministerial Declaration on the TRIPS Agreement and Public Health" 63.

Beyond the WHO, concern abounds regarding trade agreements and access to medicines. In June 2004, Catholic bishops from the U.S. and Latin America issued a joint statement in which they warned of the ill consequences of the intellectual property provisions in CAFTA 64. A month later, Paul Hunt, the Special Rapporteur of the United Nations Commission on Human Rights, declared: "I am deeply concerned that the U.S. - Peru trade agreement will water-down internationally agreed health safeguards, leading to higher prices for essential drugs that millions of Peruvians will find unaffordable" 65. Former Ecuadorian health ministers and academics recently issued an open letter to the President of Ecuador warning against agreeing to strengthened intellectual property rules with the U.S. 66 . Numerous organizations - such as the Consumer Project on Technology, Médecins Sans Frontières, Health Action International, Oxfam, Treatment Action Campaign, Act Up Paris, and the Health Gap Coalition - have carefully researched and documented current trade negotiations and the concerns associated with the provisions stipulated in trade agreements.

The poor and sick have also consistently raised voices of opposition to trade agreement negotiations in their respective countries. In mid-March 2006, Ecuadorian peasants erected roadblocks throughout the country in protest of the U.S. - Ecuadorian free trade agreement, thereby forcing the government to declare a state of emergency 67 . When Guatemala's legislature passed measures to strengthen patent law in order to facilitate CAFTA's approval, Guatemalan HIV-positive patients protested that the measures would make the already arduous task of obtaining ARV medicines even harder 68. Whether or not to ratify CAFTA became the primary issue in Costa Rica's recently concluded presidential elections between Otton Solis, an opponent of 
CAFTA, and Oscar Arias, an ardent CAFTA supporter ${ }^{69}$, although Arias was declared the winner, the election was extremely tight, in part because of growing popular skepticism about the prospects of CAFTA 70 . Whether through their votes or protests, the poor have raised consistent opposition to trade agreements that U.S. and foreign trade ministers and multinational corporations, in other words the elite, tout as "pro-poor".

\section{Conclusion}

The issues discussed above raise a number of salient questions to which the poor in the world deserve urgent, honest answers. Should matters of health constitute a state of exception from patent law? What potential benefits do bilateral, regional, and multilateral trade agreements have for resource-poor settings? Is this really "free" trade? Do current trade agreements respect the national patent law of sovereign states and allow these nations to prioritize public health? Will trade agreements stymie efforts to combat global disease, especially the AIDS pandemic? Can the intellectual property components of trade agreements be designed in a manner that is mutually beneficial for the poor and for drug innovation?

At a time when powerful countries use their financial leverage to negotiate trade agreements to expand their markets - dictating a new global economic order that has far-reaching public health implications - the promotion of global health depends on a thorough consideration of these questions. Although poverty, public health infrastructure, lack of political commitment, and poor drug quality certainly contribute to inadequate HIV treatment and are issues with which to contend, international patent law becomes another structural factor with dire implications for ART in resource-poor settings. At a time when both massive expansion of ART and the restructuring of U.S. trade relations with many nations are occurring, the relationship between international patent law and its effect on access to ARVs in the developing world needs urgent attention.

With both the intensification of trade negotiations and concern about the impact of trade liberalization on developing countries, it is vital to formulate alternative strategies that promise to mitigate the impact of strengthened intellectual property law on poor patients. One such example is the Technological Network on HIV/ AIDS, a consortium of seven countries, including Brazil, Cuba, China, Nigeria, Russia, Thailand, and Ukraine, and potentially Uruguay, India and South Africa, who aim to achieve self-sufficiency in the research, development, production, and distribution of ARVs and other related medications 71,72 . In addition, these countries aim to critically engage intellectual property law in order to ensure that patents do not prevent appropriate care of the sick. Brazil has led these efforts by reforming its laws to be able to break patents and by repeatedly threatening to break patents in order to continue providing free ART for all HIV-positive Brazilians; such threats resulted in dramatic ART price reductions from brand-name pharmaceutical companies 59. Brazil continues to encourage the disavowal of patents that hinder the provision of healthcare in low - and middleincome countries 10. Such courageous efforts must be publicly and financially supported.

Through interdisciplinary efforts, the strengthening of intellectual property law can be effectively challenged in the interests of promoting global health equity. Ultimately, increased research and advocacy must aim to effect concrete changes in the ways that intellectual property provisions are integrated into trade agreements. Such changes require that governments and pharmaceutical companies are held responsible for their self-proclaimed commitments to the common good. Numerous avenues exist for promoting these goals. The WHO should have a stronger position in bilateral, regional, and multilateral trade negotiations to ensure that public health remains a priority. In addition, WTO could create a Working Group on Health as has been suggested 73 whose recommendations would be based on WHO guidelines and recommendations. Low - and middle-income countries could simultaneously agree to restrict intellectual property law discussions to WTO forums, thereby preventing strong-arming of smaller governments in bilateral, regional, and multilateral trade negotiations. By supporting each other and working within the WTO, smaller countries will occupy a stronger negotiating position that will respect public health demands. Finally, partnerships such as the Global Alliance for TB Drug Development should be more actively supported to allow for the development of drugs that are free of patent restrictions and address the diseases of the poor.

This paper stresses the importance of examining international patent law when considering global access to ARVs. Bilateral, regional, and multilateral trade agreements threaten to construct additional obstacles in the provision of ARVs by strengthening strict patent law and thereby hindering the production of cheaper generic medications. Scrupulous consideration of structural factors, such as patent law, that thwart efforts to treat AIDS patients in resource-poor settings needs to be a top priority in order to 
combat the AIDS pandemic. These issues also extend beyond access to medications for HIV treatment: the conditions of patent law embedded in current trade agreements threaten to obstruct access to numerous essential medicines and newly developed medications, further entrenching health disparities between the wealthy and the poor. During a time of rapid advancement in medical care and treatment, such inequalities are unacceptable.

\section{Resumo}

Actualmente diversos países de renta media y baja están creando leyes de propiedad intelectual más rígidas, muchas veces para adaptarse a las exigencias de los tratados de "libre" comercio con los Estados Unidos. Tales medidas suelen incluir dispositivos que transcienden las normas sobre patentes negociadas recientemente en la Organización Mundial del Comercio, que prometían equilibrar las exigencias de la salud pública y las de patentes. Este artículo analiza la preocupación de que este endurecimiento restrinja el acceso a medicamentos esenciales, en particular en el contexto de la pandemia de SIDA. El artículo examina las amenazas potenciales creadas por los tratados comerciales contra los esfuerzos dirigidos para el acceso universal a los antirretrovirales, manteniendo que condicionar el desarrollo económico al endurecimiento de la legislación requiere una atención escrupulosamente justificada cuando la salud pública está en juego. Finalmente, se examinan algunos éxitos obtenidos por grupos de presión, concluyéndose que son necesarias más estrategias politicas y de presión para garantizar la protección de la salud mundial en las negociaciones sobre tratados internacionales de comercio.

Síndrome de Inmunodeficiencia Adquirida; Agentes Antirretrovirales; Industria Farmacéutica; Medicamentos Genéricos

\section{Contributors}

A. Castro conceived the study. M. Westerhaus obtained most of the data. Both authors drafted the article.

\section{Acknowledgements}

We are thankful to Marcia Angell, Lorena Barberia, Moira Breslin, Jim Cavallaro, Colleen Chien, Nadine Farid, Paul Farmer, Renato Gusmão, Kathryn Kempton, Vanessa Kerry, Jim Y. Kim, Sang Kim, Jo Paluzzi, Cynthia Rose, Joshua Schulman, and Aaron Shakow for our fruitful conversations on the topics presented in this paper. No competing interests declared. 


\section{References}

1. Westerhaus M, Castro A. How do intellectual property law and international trade agreements affect access to antiretroviral therapy. PLoS Med 2006; 3: e332.

2. World Intellectual Property Organization. Paris convention for the protection of industrial property. http://www.wipo.int/clea/docs/en/wo/ wo020en.htm (accessed on Nov/2004).

3. World Trade Organization. Members and observers. http://www.wto.org/english/thewto_e/whatis_e/tif_e/org6_e.htm (accessed on 25/Jan/2005).

4. World Trade Organization. Declaration on the TRIPS agreement and public health. http://www. wto.org/english/thewto_e/minist_e/min01_e/ mindecl_trips_e.htm (accessed on 12/Oct/2004).

5. Loff B. No agreement reached in talks on access to cheap drugs. Lancet 2002; 360:1951.

6. United Nations. List of least developed countries. http://www.un.org/special-rep/ohrlls/ldc/list. htm (accessed on Jan/2005).

7. 't Hoen EFM. TRIPS, pharmaceutical patents and access to essential medicines: Seattle, Doha, and beyond. In: Agence Nationale de Recherches sur le Sida, editors. Economics of AIDS and access to HIV/AIDS care in developing countries: issues and challenges. Paris: Agence Nationale de Recherches sur le Sida; 2003. p. 39-67.

8. Oliveira MA, Bermudez JA, Chaves GC, Velasquez G. Has the implementation of the TRIPS Agreement in Latin America and the Caribbean produced intellectual property legislation that favours public health? Bull World Health Organ 2004; 82:815-21.

9. Adelman K. Praise for piracy? The Washington Times 2005; 9 may.

10. Kaiser Daily HIV/AIDS Report. Drug access/Brazil requests voluntary licensing for AIDS drugs to treat more patients, reduce costs of importing patented drugs. http://www.kaisernetwork.org/daily_reports/rep_index.cfm?hint=1\&DR_ID=28706 (accessed on 21/Nov/2005).

11. Consumer Project on Technology. Recent healthrelated compulsory licenses and disputes. http:// www.cptech.org/ip/health/cl/recent-examples. html (accessed on May/2005).

12. Joint United Nations Programme on HIV/AIDS. AIDS epidemic update december 2005. Geneva: Joint United Nations Programme on HIV/AIDS; 2005.

13. Centers for Disease Control and Prevention. Global AIDS Program: countries - South Africa. http:// www.cdc.gov/nchstp/od/gap/countries/south_africa.htm (accessed on Nov/2004).

14. World Bank. Long term economic impact of HIV/ AIDS more damaging than previously thought. http://web.worldbank.org/WBSITE/EXTERNAL/ NEWS/0,,contentMDK:20120894 menuPK:34463 $\sim$ pagePK:34370 piPK:34424 theSitePK:4607,00. html (accessed on 19/Sep/2004).

15. Farmer P, Leandre F, Mukherjee JS, Claude M, Nevil P, Smith-Fawzi MC, et al. Community-based approaches to HIV treatment in resource-poor settings. Lancet 2001; 358:404-9.
16. World Health Organization. Progress on global access to HIV antiretroviral therapy: a report on "3 by 5" and beyond. http://www.who.int/hiv/fullreport_en_highres.pdf (accessed on 03/Apr/2006).

17. World Health Organization. "3 by 5" progress report - december 2004. Progress in numbers. http://www.who.int/3by5/en/numbers.pdf (accessed on May/2005).

18. World Health Organization. The WHO model list of essential medicines: 13th model list of essential medicines. http://www.who.int/medicines/ organization/par/edl/eml.shtml (accessed on Jan/2005).

19. amFAR AIDS Research. TREAT Asia special report: expanded availability of HIV/AIDS drugs in Asia creates urgent need for trained doctors. http:// web.amfar.org/treatment/news/TADoc7.pdf (accessed on 21/Nov/2005).

20. Shaw DG. Strike a balance on product patents: there are perverse incentives in the current system. http://lists.essential.org/pipermail/iphealth/2004-December/007314.html (accessed on Jan/2005)

21. Médecins Sans Frontières. Sources of affordable generic medicines drying up? India should ensure global access to medicines when amending its patent law. New York: Médecins Sans Frontières; 2005.

22. McNeil DG. India alters law on drug patents. New York Times 2005; 24 mar.

23. India's choice [Editorial]. New York Times 2005; 18 jan.

24. Kim J. WHO letter to India's health minister on patent legislation. http://www.cptech.org/ip/health/ c/india/who12172004.html (accessed on Jan/2005).

25. Joint Action Committee Against Amendment of the Indian patents act: declaration. http://www. cptech.org/ip/health/c/india/ngodeclaration 12292004.html (accessed on Jan/2005).

26. Pharmaceutical Research and Manufacturers of America. The issues: intellectual property. http:// www.phrma.org/issues/intprop/ (accessed on Jan/2005).

27. Consumer Project on Technology. Additional notes on government role in the development of HIV/ AIDS drugs. http://www.cptech.org/ip/health/ aids/gov-role.html (accessed on Jan/2005).

28. August EM, Marongiu ME, Lin TS, Prusoff WH. Initial studies on the cellular pharmacology of 3'deoxythymidin-2'-ene (d4T): a potent and selective inhibitor of human immunodeficiency virus. Biochem Pharmacol 1988; 37:4419-22.

29. Curtis J. Hunting down HIV. http://info.med.yale. edu/external/pubs/ym_su98/cover/cov_hunting11.html (accessed on Jan/2005).

30. DeYoung K, Brubaker B. HIV drug price cut for some in Africa: protesters rallied outside BristolMyers's New York offices March 5 as a South African court heard AIDS drug issues. Washington Post 2001; 15 mar.

31. Angell M. The truth about the drug companies. New York: Random House; 2004.

32. Love J, Hubbard T. Make drugs affordable: replace TRIPs-plus by R\&D-plus. Bridges 2004; 8:1-4. 
33. Chien C. Cheap drugs at what price to innovation: does the compulsory licensing of pharmaceuticals hurt innovation? Berkeley Technol Law J 2003; 18:1-57.

34. Pecoul B, Chirac P, Trouiller P, Pinel J. Access to essential drugs in poor countries: a lost battle? JAMA 1999; 281:361-7.

35. Attaran A. How do patents and economic policies affect access to essential medicines in developing countries? Health Aff 2004; 23:155-66.

36. Attaran A, Gillespie-White L. Do patents for antiretroviral drugs constrain access to AIDS treatment in Africa? JAMA 2001; 286:1886-92.

37. Dumoulin J, Flori Y-A, Vinard P, Borel T. World market strategies for drugs to fight AIDS. In: Agence Nationale de Recherches sur le Sida, editor. Economics of AIDS and access to HIV/AIDS care in developing countries: issues and challenges. Paris: Agence Nationale de Recherches sur le Sida; 2003. p. 213-44.

38. Lucchini S, Cisse B, Duran S, Cenival M, Comiti C, Gaudry M, et al. Decrease in prices of antiretroviral drugs for developing countries: from political "philanthropy" to regulated markets? In: Agence Nationale de Recherches sur le Sida, editor. Economics of AIDS and access to HIV/AIDS care in developing countries: issues and challenges. Paris: Agence Nationale de Recherches sur le Sida; 2003. p. 169-211.

39. Rosenberg T. Look at Brazil. New York Times 2001; 28 jan.

40. Stiglitz J. New trade pacts betray the poorest partners. New York Times 2004; 24 jul.

41. 't Hoen E. TRIPS, pharmaceutical patents, and access to essential medicines: a long way from Seattle to Doha. Chic J Int Law 2002; 3:27-48.

42. Coriat B, Dumoulin J, Flori Y-A, Barnett T, Souteyrand Y, Moatti J-P. Patents, generic drugs and the markets for antiretrovirals. In: Moatti J-P, Coriat B, Souteyrand Y, Barnett T, Dumoulin J, Flori Y-A, editors. Economics of AIDS and access to HIV/AIDS care in developing countries: issues and challenges. Paris: National Agency for AIDS Research; 2003. p. 27-37.

43. Kremer M, Glennerster R. Strong medicine: creating incentives for pharmaceutical research on neglected diseases. Princeton: Princeton University Press; 2004.

44. Médecins Sans Frontières. No consensus at the TRIPS council but a last opportunity to fix flaws in the TRIPS agreement. New York: Médecins Sans Frontières; 2003.

45. Médecins Sans Frontières. Access to medicines at risk across the globe: what to watch out for in the free trade agreements with the United States. http://www.accessmed-msf.org/documents/ftabriefingenglish.pdf (accessed on 21/Nov/2005).

46. Rosenberg M. Centam says trade pact stalled by medicine rules. Reuters Wire 2006; 11 jan.

47. Office of the United States Global AIDS Coordinator. The President's plan for AIDS Relief: U.S. Fiveyear global HIV/AIDS strategy. Washington DC: State Department; 2004.

48. Office of the United States Global AIDS Coordinator. Engendering bold leadership. The President's plan for emergency AIDS relief: first annual report to Congress. Washington DC: State Department; 2005.
49. Office of the United States Trade Representative. The Dominican Republic - Central America - United States Free Trade Agreement. http://www.ustr. gov/Trade_Agreements/Bilateral/DR-CAFTA/DRCAFTA_Final_Texts/Section_Index.html (accessed on $12 /$ Oct/2004).

50. Médecins Sans Frontières. Open letter to ministers of trade in countries negotiating the US-Andean Free Trade Agreement. http://www.accessmed$\mathrm{msf}$.org $/ \mathrm{prod} /$ publications.asp? scntid $=169200$ $4101603 \&$ contenttype=PARA\& (accessed on 15/ Oct/2004)

51. Blustein P. U.S., Peru strike free-trade agreement. Washington Post 2005; 8 dec.

52. Office of the United States Trade Representative. Subject to legal review for accuracy, clarity, and consistency subject to authentication of English and Spanish versions. Draft 6 January 2006. Chapter sixteen. Intellectual property rights. http:// www.ustr.gov/assets/Trade_Agreements/Bilateral/Peru_TPA/Final_Texts/asset_upload_file509_ 8706.pdf (accessed on 01/Apr/2006).

53. Office of the United States Trade Representative. United States and Colombia conclude free trade agreement. www.ustr.gov/Document_Library/ Press_Releases/2006/February/United_States_Colombia_Conclude_Free_Trade_Agreement.html (accessed on 01/Apr/2006).

54. Russell A. House Democrats criticize administration over IPR provisions in FTAS. http://lists. essential.org/pipermail/ip-health/2004-October/007018.html (accessed on Dec/2004).

55. Cohen D. Competition Commission finds pharmaceutical firms in contravention of the Competition Act. Beachhead media and investor relations. www.cptech.org/ip/health/sa/cc10162003.html (accessed on Dec/2004).

56. Galvão J. Access to antiretroviral drugs in Brazil. Lancet 2002; 360:1862-5.

57. Galvão J. A política brasileira de distribuição e produção de medicamentos anti-retrovirais: privilégio ou um direito? Cad Saúde Pública 2002; 18:213-9.

58. Teixeira PR, Vitória MA, Barcarola J. The Brazilian experience in providing universal access to antiretroviral therapy. In: Agence Nationale de Recherches sur le Sida, editor. Economics of AIDS and access to HIV/AIDS care in developing countries: issues and challenges. Paris: Agence Nationale de Recherches sur le Sida; 2003. p. 69-88.

59. BBCNews. New anti-HIV drug deal for Brazil.http:// news.bbc.co.uk/1/hi/world/americas/3281683. stm (accessed on 12/Nov/2004).

60. Raghavan C. Health: assembly adopts new revised drug strategy. http://www.twnside.org.sg/title/assembly-cn.htm (accessed on Jan/2005).

61. World Health Organization. WHO to address trade and pharmaceuticals. http://www.who.int/inf-pr1999/en/pr99-wha13.html (accessed Jan/2005).

62. World Health Organization. Revised drug strategy. http://www.who.int/gb/ebwha/pdf_files/WHA54/ ea5417.pdf (accessed Jan/2005).

63. World Health Organization. Scaling up treatment and care within a coordinated and comprehensive response to HIV/AIDS. Resolution WHA 57.14 of the 57th World Health http://www.who.int/ gb/ebwha/pdf_files/WHA57/A57_R14-en.pdf (accessed on Jan/2005). 
64. Bishops' Secretariat of Central America/Chairmen of the Domestic/International Policy Committees of the United States Conference of Catholic Bishops. Joint statement concerning the United States-Central American Free Trade Agreement (US-CAFTA). www.usccb.org (accessed on Jan/2005).

65. United Nations High Commission for Human Rights. US-Peru trade negotiations: special rapporteur on right to health reminds parties of human rights obligations. http://www.unhchr.ch/ huricane/huricane.nsf/0 /35C240E546171AC1C12 56EC800308A37?opendocument (accessed on 15/ Oct/2004)

66. Consumer Project on Technology. Carta abierta al señor presidente de la República. http://www. cptech.org/ip/health/trade/andean/ecuadorletter03232006.html (accessed on 01/Apr/2006).

67. Andrade C. Ecuador calls emergency to quell Indian protest. The Boston Globe 2006; 21 mar.
68. Daniel F. Guatemalan HIV patients slam new trade rules. http://www.alertnet.org/thenews/newsdesk/N30211004.htm (accessed on 01/Apr/2006).

69. Dickerson M, Iritani E. Trade accord with U.S. splits voters in Costa Rica. The Los Angeles Times 2006; 7 feb.

70. BBC News. Nobel laureate to lead Costa Rica. http://news.bbc.co.uk/1/hi/world/americas/ 4773220.stm (accessed on 01/Apr/2006).

71. Morel CM, Acharya T, Broun D, Dangi A, Elias C, Ganguly NK, et al. Health innovation networks to help developing countries address neglected diseases. Science 2005; 309:401-4.

72. World Health Organization. Progress on global access to HIV antiretroviral therapy: an update on " 3 by 5”. Geneva: World Health Organization; 2005.

73. Kimball AM. The health of nations: happy birthday WTO. Lancet 2006; 367:188-90

Submitted on 24/Apr/2006

Approved on 04/Sep/2006 